their weight, which was still considerable, would not be objectionable. The secondary battery was not an entirely new conception. The hydrogen gas battery suggested by Sir Wm. Grove in $184 \mathrm{I}$, and which was shown in operation, realised in the most ferfect manner the conception of storage, only that the power obtained from it was exceedingly slight. The lecturer, in working upon Sir William Grove's conception, had twenty-five years ago constructed a battery of considerable power in substituting porous carbon for platinum, impregnating the same with a precipitate of lead peroxidised by a charging current. At that time little practical importance attached, however, to the subject, and even when Planté, in 1860, produced his secondary battery, composed of lead plates peroxidised by a charging current, little more than scientific curiosity was excited. Jt was only since the dynamo-machine had become an accomplished fact that the importance of this mode of storing energy had become of practical importance, and great credit was due to Faure, to Sellon, and to Volckmar, for putting this valuable addition to practical science into available forms. A question of great interest in connection with the secondary battery had reference to its permanence. A fear had been expressed by many that local action would soon destroy the fabric of which it was composed, and that the active surfaces would become coated with sulphate of lead preventing further action. It had, however, lately been proved in a paper read by Dr. Frankland before the Royal Society, corroborated by simultaneous investigations by Dr. Glad-tone and Mr. Tribe, that the action of the secondary battery depended essentially upon the alternative composition and decomposiţion of sulphate of lead, which was therefore not an enemy, but the best friend to its continued action.

In conclusion, the lecturer referred to electric nomenclature, and to the means for measuring and recording the passage of electric energy. When he addressed the British Association at Soutbampton, he had ventured to suggest two electrical units additional to those established at the Electrical Congress in $188 \mathrm{I}$, viz., the Watt and the Joule, in order to complete the chain of units connecting electrical with mechanical energy and with the unit-quantity of heat. He was glad to find that this suggestion had met with favourable reception, especially that of the Watt, which was convenient for expressing in an intelligible manner the effective power of a dynamo-machine, ald for giving a precise idea of the number of lights or effective power to be realised by its current, as well as of the engine power necessary to drive it : 746 Watts represented I h.p.

Finally the Watt-meter, an instrument recently developed by his firm, was shown in operation. This consisted simply of a coil of thick conductor suspended by a torsion wire, and opposed laterally to a fixed coil of wire of high resi-tance. The current to be measured flowed through both coils in parallel circuit, the one representing its quantity expressible in Amperes, and the ther its potential expressible in Volts. Their joint attractive action expressed therefore Volt-Ampères or Watts, which were read off upon a scale of equal divisions.

The lecture was illustrated by experiments, and by numerous diagrams and tables of results. Measuring instruments by Professors Ayrton and Perry, by Mr. Edison and by Mr. Boys were also exhibited.

\section{FAUNA AND FLORA OF THE ALEUTIAN} ISLANDS

THE last number of Naturen contains an interesting report by Dr. Leonhard Stejneger of the result of his six months' observations of the fauna and flora of the Kamschatkan coast and of the so-called Kommandorski Islands, which form the western group of the Aleutian archipelago between Behring's Sea and the Pacific, in $50^{\circ}-55^{\circ} \mathrm{N}$. lat. The Kommandorski group consists of tho islands, one of which is known as Mednoj Ostrov, Copper Island, from the large amount of the pure metal found there ; while the other, which was the scene of Behring's shipwreck and death, bears his name. Both islands are geologically allied to Kamschatka, and excepting at the north of Behring's Island, where the gradual subsidence of the sea has left raised beaches, terraces, and tabulated rock-formations, the islands consist generally of deep narrow valleys separated by rocky barriers, which rite precipitously to a beight of from 1000 to 2000 feet above the level of the sea. The islands, which were uninhabited before their annexation by Russia, are now occupied by about 700 persons, in the employment of a Russo-
American fur company, which has been attracted to the spot by the enormous numbers of sea-bears (Callorhinus ursinus) and sea-oiters (Enhydra lutris) which frequent the coasts. The climate is foggy, and the vegetation stunted and sparse, while in the neiyhbouring Kamschatkan territory the blue of the summer sky, the stillness of the sea, and the softness of the air, are almost Italian in character. The flora, moreover, is so exuberant that numerous plants, which in Norway never exceed two or three feet, here attain the height of a tall man. Next to the birch (Betula ermanni), alders, willows, and roans (Sorbus Kamschaticus), are the most frequent trees, the berries of the last-named, and those of Lonicer a carulea, $p$ 'ssessing a sweetnes s which brings them into great request among strangers as well as natives. Some flower also, as the wild, indigenous, dark red rise, several rh dodendrons, and native lilies, are :qually remarkable for exceptional fragrance. Among wild flowers, some of the geraniums, poten tillas, taraxacums, \&c., are almost identical with those fuund in Norway. Besides a large whale, and a specimen of the walrus (Rosmarus obesus), which had been killed near Avatscha Bay, Dr. Stejneger could find no trace of any mammal but a small specimen of Arvicola aconomus. Of birds there is, however, an enormous variety, some of which, as Calliope Kamschatica, Carpodacus Ery. thrinus, and a kind of sedge-warbler, provisionally named by the author "Acrocephalus dybowskii," combine an almost tropical brilliancy of colouring with a sweetness of song equal to that of our own nightingale or thrush. Besides these melodious warblers, Kamschatka harbours large numbers of Locustella lanceolata, whose grasshopper-like cry is heard when all else is still. Cuculus canorinus represents our common cuckoo. Pipits, chats, and wagtails abound; Larus capistratus is commoner than any other gull, and the osprey is not unfrequent. Mosquito-like gnats of vindictive nature swarm in such numbers as to make the pursuits of the field naturalist almost impracticable. The fauna, generally, is palæarctic in character, with a scarcity of American forms which is very remarkable when we consider the vicinity of the western continent.

\section{PHYSICAL HISTORY OF THE DEAD SEA,} THE FORDAN VALLEY, AND PALESTINE

PROF. E. HULL, LL.D., F.R.S., delivered an interesting lecture on the above subject on March 2, in the Theatre of the Royal Dublin Society's premises, Kildare Street. Prof. Hull said :- "There is no country which possesses for us an interest equal to that which I have to treat of this evening. Its religious and historical associations stand alone amongst those of all nations, and will ever maintain in the history of the world an undying import. But while this is true as regards the religious and social aspects of Palestine, I hope to show that in its physical aspect it possesses points of interest which render it unique amongst all countries, and which have attracted to it the attention of naturalists during a lengthened period down to the present day. Probably no country has been so often described. Its physical features bave attracted the attention of observers of natural phenomena from Strabo downwards to the recent admirable work of M. Lartet and the Duc de Luynes, to which I am largely indebted. In more recent times we have the observations of Humboldt, of the late Dr. Hitchcock, of Lieut. Lynch of the United States Navy, who carried out a systematic series of soundings over the bed of the Dead Sea, and more recently of the Rev. Dr. Tristram, of Prof. Roth, Burkhardt, and others, including the Survey made by the officers of the Royal Engineer:. It is curious however that the remarkable physical phenomenon which renders the Holy Land unique among:t all countries (regarded in its physical aspect) was not discovered till the year 1836-37, when Heinrich Von Schubert and Prof. Koth determined by barometric observations that the surface of the Dead Sea lies no less than 1300 feet below the level of the Mediterranean, a fact not suspected by previous observers. It is the deep depression of the Jordan Valley, deeper by far than any river valley elsewhere, which is the key to the physical history of the whole country; and in endeavouring to trace out its origin I : hall reproduce in as general a manner as I can the successive phases through which the region bordering the Mediterranean, and extending eastwards towards the Euphrates and southwards to the Dead Sea, has passed. The fundamental basis of the geological formation of Palestine is the gneissic granite, of Archrean age and metamorphic origin, which rises into the mountains of Idumea, and is the rock from which the huge 